\title{
LEGAL DEVELOPMENT OF NON-MARITAL UNION IN CROATIA
}

\section{Aleksandra KORAĆ GRAOVAC ${ }^{1}$}

Legal development of non-marital union in Croatia went through different phases - from modest family law effects (property rights and the right to maintenance) in late seventies of the twentieth century to equating non-marital union with marriage nowadays, except the establishment of fatherhood and gaining common family name.

In the Family Act (2015) non-marital union refers to a life union between an unmarried woman and an unmarried man that has lasted for at least three years or for a shorter duration if a common child has been born therein or has been continued by entering a marriage.

The author underlines the problem of legal uncertainty that arises from the fact that non-marital union is informal and that preconditions for non-marital union effects are different in different legal branches. Overall, legal regulation of non-marital union in Croatia is inconsistent due to particular legal solutions.

\begin{tabular}{l|l} 
Croatian family law \\
non-marital union \\
non-marital spouses \\
cohabitation \\
children born out of wedlock
\end{tabular}

\section{Introduction}

All historical periods have been witness to informal life unions, which continue to take place today. Sometimes, they resulted from the inability to enter into marriage; at other times, they reflected women's weaker position when a man did not want to marry for various reasons. In modern times, they have tended to become a sort of lifestyle in many states.

Historical and social approaches differ depending on the legal effects of such unions. In modern times, fewer and fewer marriages are being concluded in the European states, while an increasing number of couples are deciding to live in a non-marital union

1 | Professor, Faculty of Law, University of Zagreb, Croatia, aleksandra.korac.graovac@pravo.hr, ORCID: 0000-0003-2685-8876. 
(cohabitation). This trend is also seen in the Republic of Croatia, although marriage is still the main form of life union in which a vast number of children are born. However, the number of marriages entered into is declining, with the marriage rate in 2020 at 3.8 per 1,000 residents. ${ }^{2}$ As opposed to the number of marriages entered into, which is easy to track, the number of established non-marital unions can be obtained only by means of a population census, which is implemented every ten years.

According to the most recent population census conducted in $2011,{ }^{3}$ there were 959.487 couples living in marriage and 48.886 couples in non-marital union (out of the total number of heterosexual family unions, 95\% of them constituted marital unions, whereas 5\% were non-marital unions).

Based on the number of children born out of wedlock, one may draw an indirect conclusion about the larger representation of non-marital unions as a family form. In 2011, $14 \%$ of children were born out of wedlock (rose to $20.7 \%$ in 2020), ${ }^{4}$ but there is no data on how many of those parents live together in family unions.

Developments in the legal approach towards non-marital unions in the Republic of Croatia ranged from denying any effects and recognising limited effects only between non-marital spouses to completely equating non-marital union to marriage. The developments were specific since non-marital union has always been an informal relationship- , and the recognition of the effects has been dependent on the fact which legal effects of non-marital union need to be recognised.

Since the introduction of the institution of non-marital union into the Croatian family law in 1978, the effects of non-marital unions have been almost entirely equated to those of marriage, not only in family law, but also in other legal fields.

\section{Historical overview of legal regulation of non-marital union}

\section{| 2.1. Period before legal regulation}

During the socialist Yugoslavia after the Second World War (Federative People's Republic of Yugoslavia and Socialist Federative Republic of Yugoslavia), courts did not recognise the effects of non-marital unions, which were deemed immoral by society. ${ }^{5}$ The legal approach also changed gradually to prevent exploitation of the weaker side, which regularly happened to be women, after the termination of a non-marital union.

In 1954, the Federal Supreme Court issued an instruction according to which nonmarital spouses were not eligible for rights such as mutual maintenance and inheritance. On the other hand, for non-marital spouses who had lived in a more durable union similar

2 | Natural Change In Population In The Republic Of Croatia, 2020, First release. Available at: https:// www.dzs.hr/Hrv_Eng/publication/2021/07-01-01_01_2021.htm (Accessed: 25 August 2021).

3 | Population and Housing Census. Available at: https://www.dzs.hr/hrv/censuses/census2011/ censuslogo.htm

(Accessed:1September 2021).

4 | Statistical Information, Zagreb, 2020, p. 20. Available at: https://www.dzs.hr/Hrv_Eng/StatInfo/ pdf/StatInfo2020.pdf(Accessed:1 September 2021).

5 | Non-marital union is nevertheless not unknown to some Croatian regions, e.g., Slavonia, in the form of a 'probationary marriage'. Since it was of essence to make sure there is an heir to the estate, marriage was entered into only after it was certain that the woman would give birth and thereby guarantee an heir to family property. 
to marriage, the effects of such a union were to be recognised if it had given rise to parties' considerable property interests. The instruction ordained that property disputes were to be resolved by applying general rules of property law: on acquisition of ownership and other rights in rem, such as condictio sine causa and societas. ${ }^{6}$

Not only did the instruction deal with a problem for which there was absolutely no solution in positive law then in force, but it also served as a basis for a further evolution of the case-law and subsequent legislative intervention. ${ }^{7}$

The application of general civil law (societas and condictio sine causa) to property relations of non-marital spouses remains important even today in cases pertaining to property relationships between a woman and a man, where their life union does not meet the conditions for non-marital union required by the law. This paper will deal only with heterosexual non-marital unions since a different legal term is used in Croatian law for same-sex life unions, namely the one of life partnerships.

\section{| 2.2. Development of legal regulation}

It was the Act on Marriage and Family Relations of the Republic of Croatia ${ }^{8}$ of 1978 that first introduced in family law the institution of non-marital union, which it defined as a life union between a woman and man lasting for a prolonged period and producing maintenance effects and effects of acquiring joint property, just like marital union (Art. 7, 254 and 293). ${ }^{9}$

Thus, the law considered non-marital union to be a form of inter-personal status ${ }^{10}$ for which an informal life union was sufficient, while the essential features thereof were heterosexuality, monogamy, and durability. The last category was determined as a legal standard, and it was up to courts to ascertain, based on the circumstances of a particular case, whether a relationship displayed the elements of durability. Although it enabled individualisation, such an approach led to similar cases being treated differently, which was considered a downside.

In the same year, the Civil Obligations $\mathrm{Act}^{11}$ provided that the statute of limitations shall not run between two persons as long as they live in a non-marital union ( Art. 381, para. 4), and that a non-marital spouse was entitled to compensation in case of death of their spouse, provided that there was a more permanent non-marital cohabitation between them and the deceased or injured person (Art. 201, para. 4).

6 | Cf. Draškić, 1988, pp. 140-163.

7| Draškić, 2015, p. 136.

8 | The Act on Marriage and Family Relations, Official Gazette Nos. 11/78, 27/78, 45/89, 51/89 - official consolidated version, 59/90, 25/94,162/98.

9 | Yet, non-marital union as a legal term has been introduced into the legal system a little earlier, namely by virtue of the Housing Relations Act. The provision of Art. 9, para. 4 covered persons permanently living in a non-marital union, if such a union may be equated to marriage. Housing Relations Act of SR Croatia, Official Gazette No. 52/74.

10 | For more see: Bradley, 2001, p. 33, footnote 38, cited by Kovaček-Stanić, 2014, p. 185.

11 | Zakon o obveznim odnosima (The Civil Obligations Act), SFRY Official Gazette, No. 29/78. 
In 1990, the Constitution of the Republic of Croatia' ${ }^{12}$ elevated the institution of nonmarital union to the level of a constitutional category: 'The marriage and legal relationships in marriage, non-marital union and family shall be provided for by law' (Art. 62, para. 3).

The first family law regulation of independent and post-transitional Croatia, ${ }^{13}$ which was enacted in 1998, introduced only minor amendments to the definition of non-marital union to highlight the principle of monogamy: in order for non-marital union to produce legal effects, neither the woman nor the man in such a relationship were permitted to be simultaneously in a wedlock (Art. 3). Legal effects remained the same: property relations and maintenance.

Five years later, prompted by calls to harmonise the case law, the new Family Act introduced the duration of non-marital union as three years or less if a common child had been born therein (Art. 3 of the Family Act 2003). Family law effects remained limited to mutual maintenance and property relations and did not entail the possibility of adopting children. Marriage was still the preferred form of union in this regulation as well as in the new legislative period. ${ }^{14}$

The Family Act retained limited family law effects, but non-marital unions became an institution and started producing legal effects not only between non-marital spouses, but also in other legal fields. Thus, the Inheritance Act, ${ }^{15}$ adopted the same year, included nonmarital spouses in the circle of statutory heirs who were first-degree relatives, but set forth the conditions for non-marital union differently, that is, the life union should have lasted for a prolonged period and the preconditions for marriage validity should have been met. Newly enacted regulations caused a disagreement as to what conditions non-marital unions had to meet in order for a non-marital spouse to have the status of a statutory heir. Lex posterior and lex specialis arguments were drawn upon in the discussion in favour of applying the definition in the Family Act to other legal fields as well, ${ }^{16}$ but the case law is still not uniform even at the level of the Supreme Court ${ }^{17}$ given the element of duration of non-marital union present in these two regulations, which may find expression in cases where preconditions for marriage validity would not be met.

12 | Ustav Republike Hrvatske (Constitution of the Republic of Croatia), Official Gazette Nos. 56/90, $135 / 97,08 / 98,113 / 00,124 / 00,28 / 01,41 / 01,55 / 01,76 / 10,85 / 10$ and 05/14.

13 | Obiteljski zakon (The Family Act), Official Gazette, Nos. 162/98 and 116/03.

14 | A traditional approach to family, which favoured marriage as a form of living together, appears also in the Discrimination Prevention Act (2008) according to which 'disadvantage in regulating rights and obligations in family relations when provided for by the law, in particular for the purposes of protection of rights and interests of children, to be justified by a legitimate purpose, protection of public morale, as well favouring of marriage pursuant to the provision of the Family act' shall not be regarded as discrimination (Art. 9, para. 2[10]). Already in 2012 that protection was weakened due to a requirement made to the effect that the applied means had to be appropriate and necessary. Zakon o suzbijanju diskriminacije (The Anti-discrimination Act, Official Gazette) Nos. $85 / 08$ and $112 / 12$.

15 | Zakon o nasljeđivanju (The Inheritance Act), Official Gazette Nos. 48/03, 163/03, 35/05, 127/13, $33 / 15$ and $14 / 19$.

16 | See to that effect, Hrabar, 2003, p. 77. For a contrary view, see Crnić, 2003, p. 249.

17 | Decision of the Supreme Court of the Republic of Croatia No. Rev 783/2010-2 of 25 July 2012 referred to the three-year period provided by the Family Act as a criterion for the legal standard for 'prolonged period'. On the other hand, in an earlier decision (No. Rev 796/2008-2 of 27 January 2010), the Supreme Court of the Republic of Croatia indicated that the notion of non-marital union from the Family Act was not to be applied in other relations not regulated by the Family Act. 
The necessity to protect families of persons disabled in war or peacetime led in 1992 to the inclusion of non-marital spouses in the circle of family members of veterans disabled in war or peacetime or civil persons disabled in wartime, giving them certain rights if they had lived for at least one year in a common household prior to the death of the nonmarital spouse or if they had a common child. ${ }^{18}$

In 2004, the legal system went on to protect non-marital spouses of Croatian veterans of the Homeland War in the matter of veterans' family pensions. The condition was that prior to death, detention, or disappearance of a veteran, they had lived with their partner in a common household for at least three years. To prevent abuse, the Act provided that the existence of non-marital unions is to be established in a non-contentious procedure (Art. 6, paras. 2 and 3 of the Act on Rights of Croatian Veterans from the Homeland War and their Families). ${ }^{19}$

After recognising the right of a non-marital spouse to veterans' family pension, the Constitutional Court emphasised the unconstitutionality of the pension insurance scheme and stated the following:

Family in the Republic of Croatia is under a special protection of the State and thus represents a protected constitutional domain. On the other hand, marriage and non-marital union are unions recognized by the Constitution. As regards family, the Constitution does not differentiate between marital and non-marital union. Both types of unions are recognized by the Constitution and both are regulated by the law. Building on Article 61 of the Constitution which recognizes two types of family union (marital and non-marital one) and taking into account legal nature and purpose of family pension in the pension insurance scheme (see point 1 of this Report), the Constitutional Court finds that ZOMO [the act governing pension insurance] should also regulate the conditions for entitling not only marital widow(er)s, but also non-marital widow(er)s to family pension. ${ }^{20}$

The ruling was followed by a period marked by recognition of the effects of nonmarital unions in other legal fields (non-marital spouses have become beneficiaries of medically assisted procreation, they have entered the circle of persons covered by the law dealing with family violence, etc.). Finally, by virtue of an amendment added and accepted on the very day of voting that happened without a public debate, the Family Act 2014, in principle, equated informal non-marital union to marriage with regard to all the effects. The right of non-marital spouses to jointly adopt a child was explicitly introduced.

The only legal branch that differed in the treatment of non-marital spouses was tax legislation, which did not grant tax exemptions for property contracts or inheritance. After the decision of the Constitutional Court, tax legislation was changed in favour of

18 | Zakon o zaštiti vojnih i civilnih invalida rada (The Act on Protection of Disabled Veterans and Civil Persons Disabled in Wartime) Official Gazette Nos. 33/92, 57/92, 77/92, 86/92 - official consolidated version, 27/93, 58/93, 2/94, 76/94, 108/95, 108/96, 82/01, 94/01,103/03,148/13 and 98/19.

19 | Zakon o pravima hrvatskih branitelja iz Domovinskog rata i njihovih obitelji (The Act on Rights of Croatian Veterans from Homeland War and of Their Families) Official Gazette Nos. 174/04, 92/05, 2/07, 107/07, 65/09, 137/09, 146/10, 55/11, 140/12, 19/13 - official consolidated version, 33/13, 148/13, 92/14 and 121/17.

20 | Report on Detected Unconstitutionality within Pension Insurance Scheme

No.:U-X-1457/2007; Zagreb, 18 April 2007. Available at: https://zakon.poslovna.hr/public/izvjesce-ouocenoj-pojavi-neustavnosti-u-sustavu-mirovinskog-osiguranja/417094/zakoni.aspx. (Accessed 19 August 2021) 
non-marital spouses. The Constitutional Court highlighted the fact that non-marital and marital spouses were not treated in the same way by the tax law:

It is impossible for the Constitutional Court to continue accepting the administrative practice and the case-law consisting of a restrictive and mechanical interpretation of the notion "marital spouse" when applying the Act on Real Estate Transfer Tax. The Constitutional Court finds no objective and reasonable justification for the difference in treatment towards the applicant as a non-marital spouse when applying the provisions on tax exemption from payment of real estate transfer tax. ${ }^{21}$

\section{Non-marital union in modern-day Croatian legislation}

\section{| 3.1. Family law effects}

According to the Family Act of 2015, which was in force at the time of the writing of this paper, ${ }^{22}$ non-marital union refers to a life union between an unmarried woman and an unmarried man (principle of monogamy and heterosexuality) that has lasted for at least three years or for a shorter duration if a common child has been born therein or has been continued by entering into a marriage (Art. 11, para. 1).

The novelty lies in the determination that a non-marital union may last for less than the specified duration if it was continued by entering into a marriage, which implies adhering to the case-law wherein it was construed that even in a short-term non-marital union, there is property continuity if the relationship was consolidated through marriage, which is a 'stronger' institution in terms of status. ${ }^{23}$ Non-marital union is equated to marital union so as to

21 | Decision of the Constitutional Court of the Republic of Croatia, No. U-III/3034/2012 of 21 February 2017. Cited by Lucić, 2020, p. 194.

22 | Obiteljski zakon (The Family Act), Official Gazette, Nos. 103/15, 98/19 and 47/20. This regulation replaced the Family Act, Official Gazette Nos 75/14, 05/15, 103/15, which was suspended by the Constitutional Court of the Republic of Croatia, but which contained identical provisions pertaining to non-marital union.

23 I When applying the Family Act from 2003 in its decision in 2012, the Supreme Court took the position that the property of a non-marital spouse that existed before the formation of a nonmarital union represents a unique continuity of property after entering into marriage, even if the non-marital union has not lasted for at least three years or a common child has not been born therein. At issue was the case of a famous athlete who first lived in a non-marital union, which was continued after less than three years by a marriage in which a child was born shortly after it had been entered into. During the non-marital union, the man concluded an exceptionally valuable sports contract. Interestingly enough, the Supreme Court pointed out in the statement of grounds that the quality of parties' union was improved. 'In the case at hand at issue is the non-marital union of the parties which changed its form after less than three years by entering into a marriage of the parties in which their common child was born. In light of the continuity of the parties' union, and in particular of the improvement of its quality (in relation to the legal status), this court concludes that it must be held that the continuity of (non-)matrimonial property belonging first to non-marital and thereafter to marital spouses is present here'.

Rev 1364/10-2, Supreme Court of the Republic of Croatia.

For an anticipated possibility of such an approach see Korać u Alinčić et al., 2007, p. 523, and for an anticipated criticism invoking protection of the principle of legality see Hrabar, 2010, pp. 43-46. 
produce personal and property effects like a marital union and provisions of this Act governing personal and property relations of marital spouses, i.e. provisions of other acts governing relations in tax matters as well as personal, property and other relations of marital spouses apply mutatis mutandis thereto (Art. 11, para. 2).

Moreover, family regulation repealed the Anti-discrimination Act in light of its disadvantageous treatment of non-marital spouses in terms of access to benefits, privileges, and other assistances guaranteed to marital spouses, which cannot be justified by objective reasons and represents discrimination on the grounds of family status (Art. 11, para. 3.). Nevertheless, the inability of non-marital spouses to change the family name does not represent disadvantageous treatment (Art. 11, para. 4).

This provision represented a firm expression of the political will to have the effects of non-marital union equated to those of marriage, which is why a provision to that effect was introduced into family law regulation. Admittedly, it should be pointed out that at that moment, it had already produced legal effects in the majority of legal fields, save for real estate transfer taxation (see infra). In line with these trends, non-marital spouses have also been enabled to jointly adopt a child (Art. 185). ${ }^{24}$

In summary, the non-marital union of a man and a woman produces similar family law effects as those pertaining to the personal rights and duties of marital spouses, including the possibility of adoption, maintenance during and after the termination of a non-marital union, and property effects.

It does not produce legal effects at the time of its formation, but rather with the passage of time or by virtue of materialised facts that are legally relevant (birth of a child or entry into a marriage). 'Therefore, non-marital union is characterised by its suspensive character'.25

Thus, in property relations, for example, there will be retroactive effects for the period prior to the lapse of the three-year period, birth of a child, or entry into marriage, which means that non-marital spouses who want to avoid such consequences should conclude a prenuptial agreement, i.e., an agreement on property relations.

As for parental care, there has been no change to the rights and duties of parents of a child born out of wedlock, because since 1978, parents have had the same rights and duties with respect to their child, regardless of whether the child had been born in or out of wedlock. The father of the child born out of wedlock may be determined by recognition or a judicial decision (Art. 60 and further). When parents live in a non-marital union, the involved male may recognize the child when the birth of the child is reported, and he is going to be determined as a father upon the mother's consent.

According to the law, parents are obliged to exercise parental care jointly, on an equal footing, and by agreement (Art. 103, para 1). In case of termination of a non-marital union, parents may continue to exercise parental care, but it is up to the good will of parents to

24 | From a historical point of view, there has existed an unabated resistance to enabling a nonmarital spouse to adopt a child. Arguments that there was no procedure similar to divorce procedure within which children's rights could be protected in case of termination of non-marital union have been brought forward in support of the limitation. More recently, an objection was raised to the effect that opening the floodgates to adoption by non-marital spouses may also give rise to successful claims of the same rights by same-sex couples, which appears dubious in light of the best interests of the child.

25 | Hrabar, 2010, p. 46. 
freely agree on the manner and frequency of maintaining contact with the child and on the maintenance amount. Such a state of affairs may be a reflection of either particularly good relations between parents (which is a rare occurrence) or ignorance, i.e., the inability of one of the parents to institute proceedings leading to a clear legal situation as regards the exercise of parental care.

The child as well the parents will be better protected if the parents adopt a plan on joint parental care, ${ }^{26}$ which has to be approved by a court in a non-contentious court proceeding to be enforceable (Art. 107). Should they fail to reach an agreement, it is possible to initiate proceedings regarding parental care, personal relations of the child with the parents, and maintenance of the child (Art. 408-422 of the Family Act 2015). A former non-marital spouse has the right to contact a child and vice versa just like any other person who has lived in a family with the child for a long time, when they have taken care of and developed an emotional relationship with the child (Art.120, para. 2).

The same rules on the maintenance of marital spouses are applicable to the maintenance of non-marital spouses, including a mutual maintenance obligation during the period when they live in a non-marital union. ${ }^{27}$ Non-marital spouses may regulate maintenance by agreement (Art. 302) or court proceedings. Should they fail to conclude an agreement and the non-marital union is terminated, application for maintenance is to be filed by a non-marital spouse within a period of six months after its termination (Art. 303 of the Family Act 2015). The issue of establishing the day on which a non-marital union was terminated remains open, considering its factual nature.

Maintenance is determined according to the needs of the maintenance beneficiary and the capabilities of the provider, while the maintenance obligation may last up to one year depending on the duration of the non-marital union and the possibility of the applicant providing other means of subsistence in the foreseeable time. In justified cases, courts may prolong the maintenance obligation, an application for which may be filed only until the expiry of the period for which the maintenance has been imposed (Art. 298 in connection with Art. 304 of the Family Act 2015). The legislature has not set a period by which the maintenance obligation may be prolonged, which is why this issue has been left to the discretion of case law. Like marital spouses, non-marital spouses are first called upon to maintain their partners (Art. 283, para. 2), but one must wait for the non-marital union to begin producing legal effects.

The property relations of non-marital spouses are regulated in the same way as those of marital spouses. By operation of law, non-marital spouses may have non-matrimonial property in which they co-own equal parts or they may regulate their relations through

26 | Pursuant to Art. 106. of the Family Act 2015, 'the plan on joint parental care is a written agreement of the parents on the manner in which joint parental care is to be exercised in the circumstances in which parents of the child do not live permanently in a family union', whereby they are to regulate in detail the place and address where the child is to live, time the child is to spend with each of the parents, mode of information exchange in relation to giving consent when making decisions essential for the child, exchange of important information in connection with the child, the maintenance amount as the obligation of the parent with whom the child does not live, as well as the manner in which future contentious issues are to be resolved. By virtue of the plan on joint parental care, parents may also regulate other issues pertaining to exercise of parental care they deem essential for the child.

27 It is difficult to conceive a life situation in which one non-marital spouse sues the other for maintenance, while the non-marital union continues to exist despite disturbed relations between the spouses that led to the litigation. 
a contract. It is not logical to expect persons who are not inclined to formalise their union by means of a marriage to conclude a contract governing property relations, but they are nevertheless left with that option as well. The freedom to dispose of and manage property in legal transactions is altered for a person in a non-marital union, which, due to its informal nature, still exhibits legal uncertainty in relation to the protection of third persons.

The speed at which the amendment equated the effects of non-marital union to those of marital union also brought about certain deficiencies. Thus, the legislature omitted to provide that non-marital spouses may not be in a registered life partnership as registered partnerships preclude entering into marriage.

There is no answer if somebody lives in multiple, parallel, and non-marital unions. Analogy in interpretation can hardly be derived from the principle of monogamy in marriage, as non-marital unions are not formalised.

The deficiency also consists of the fact that some provisions contain while others do not contain the syntagms marital or non-marital spouse in their wording. The consequence is that an employee of a social welfare centre and their marital or non-marital spouse may not conclude with a person placed under guardianship a contract to dispose of or encumber that person's property (Art. 261, para. 5), while only a marital spouse has been referred to in the same chapter on guardianship as the one having the obligation to inform the social welfare centre of the need to place a person under guardianship (Art. 273, para. 2/2).

Relations towards third persons, above all children, constitute a far greater problem. The legislature has clearly provided that stepfathers and stepmothers have rights as well as a maintenance responsibility towards stepchildren under certain conditions, but there is no such stipulation for non-marital spouses. It seems unfair that non-marital spouses are exempted from the obligation to maintain the child of their non-marital spouse, especially since the obligation of relatives by marriage has been introduced precisely in order to prevent evasion of payment for child maintenance by biological relatives. It is expected that case law will close these loopholes in favour of children.

\subsection{The effects of non-marital union in the legal system}

Based on their status, non-marital spouses have rights and obligations in the legal system just like marital spouses, although some differences exist in the determination of the notion of non-marital union and/or means of proof. Among the regulations recognising the effects of non-marital unions, some of them only mention the rights of nonmarital spouses without defining non-marital unions, and others define non-marital unions, but give it a different connotation than the one in family regulation while only rarely referring to a family regulation; in addition to defining a non-marital union, some regulations provide the means to prove its existence.

According to the Act on Protection Against Domestic Violence, ${ }^{28}$ family is within the meaning of that act constituted by a man and a woman in a non-marital union and encompasses either of their children and their common children (Art. 3[1]). There is no mention of any conditions other than a factual union, independent of the duration, which 


\section{\begin{tabular}{l|l}
64 & LAW, IDENTITY AND VALUES \\
$1 \mid 2021$
\end{tabular}}

is clear in light of the act's purpose of protecting as many persons suffering from domestic violence as possible.

As mentioned above, the Civil Obligations Act $^{29}$ states that the statute of limitations shall not run between two persons as long as they live in a non-marital union (Art. 235) and entitles non-marital spouses to pecuniary compensation for non-material damage in case of death or severe disability of a close person. In order for non-marital spouses to acquire that right, it is necessary that a more lasting life union exists between them and the deceased non-marital spouse (Art.1101, para. [2]). For the purpose of applying the Civil Obligations Act, the Supreme Court did not apply the definition of non-marital union under the Family Act. ${ }^{30}$

Pursuant to the Penal Code,$^{31}$ a non-marital spouse is deemed to be a family member, while within the meaning of the Penal Code, a non-marital spouse is a person living in a non-marital union that is of a durable character or one that lasts for a shorter period of time but a common child has been born therein (Art. 87 para. [10] of the Penal code). Certain offences become aggravated if they are committed in relation to non-marital spouses, who are under no obligation to report the planning or commission of a criminal offence. According to a penal law provision, which is perhaps the most important for non-marital union, an extramarital relationship between an adult and a child younger than 16 years constitutes a criminal offence, as is the enabling or inducement of children younger than 16 years to live in an extramarital relationship (Art. 170). This provision could and should impact the recognition of the effects of non-marital unions, as living in such non-marital unions is a criminal offence, and as such, contrary to the public order. The judge should consider the circumstances of a particular case and always bear in mind the best interests of the child, including the fact that child has lived or is living in a nonmarital union.

Under the Foreigners Act, ${ }^{32}$ a non-marital spouse is a family member entitled to seek temporary residence for the purpose of family reunification. This regulation refers to the definition of non-marital union in family regulation, while temporary residence for the purpose of family reunification is not permitted if a non-marital spouse has already entered into a marital union, ${ }^{33}$ is in a long-lasting relationship with another person, or does not live in an actual marital or extramarital relationship (Art. 64 para. [1] and Art. 64 paras. [5] and [6]). Non-marital spouses are entitled to autonomous residences, but in any case, it has to be established whether non-marital spouses actually live in a nonmarital relationship. In the case of non-marital unions based on self-interest (if it was entered into to circumvent conditions necessary for entry and residence of third-country

29 | Zakon o obveznim odnosima (The Civil Obligations Act, Official Gazette), Nos. 35/05, 41/08, $125 / 11,78 / 15$ and 29/18.

30 | Decision of the Supreme Court of the Republic of Croatia, Rev. No.796/2008-2 of 2 January 2010. Available: https://www.iusinfo.hr/document?sopi=VSRH2008RevB796A2 (Accessed: 9 September 2021).

31 | Kazneni zakon (The Penal Code), Official Gazette, No. 125/11, 144/12, 56/15, 61/15 , 101/17, 118/18, $126 / 19$ and $84 / 21$.

32 | Zakon o strancima,(The Foreigners Act), Official Gazette No.133/20.

33 | The notion of marital union designates factual substance of marriage and does not have to overlap ratione temporis with the marriage itself. It is therefore obvious that terminology was put to wrong use. The legislature should have respected the terminology and used the term marriage. 
nationals), temporary or permanent residence shall not be granted for the purpose of family reunification (Art. 57, para. [2]).

According to the Social Welfare Act, ${ }^{34}$ in the social welfare system, non-marital unions have the same effects as marriage and are determined as the life union of unmarried women and unmarried men who meet the conditions provided for by family regulation (Art. 4).

The Inheritance $A c t^{35}$ contains in Art. 8, para. (2) a definition of non-marital union that differs from the one in the family regulation:

By operation of law, a deceased person's property is to be inherited by his or her non-marital spouse, who is equated to a marital spouse in inheritance law. Within the meaning of this Act, non-marital union is deemed to be a life union of an unmarried woman and unmarried man, which has endured for a long period and was terminated by the deceased person's death, provided that preconditions required for the validity of marriage had been met.

Such preconditions may lead to a situation in which someone has the status of a nonmarital spouse regarding property effects of non-marital union, while the right to inheritance has been denied due to the existence of a marriage impediment (for example, the fact that a person has been deprived of legal capacity without it being established whether the guardian has given consent to form a non-marital union ${ }^{36}$ ).

Furthermore, the Inheritance Act does not contain provisions on the means to prove the existence of non-marital unions. Since the inheritance procedure is first conducted before a notary public, it is easy for a person to represent herself or himself as a non-marital spouse and claim inheritance, while the notary public has no power of inquiry and can refer parties to judicial litigation only in case of opposition by an heir. In relation to this issue, different solutions have appeared in legal doctrines. First, in case a person in the inheritance procedure bases their right to inheritance on an extramarital relationship with the deceased person, they may demonstrate their capacity as a non-marital spouse in the proceedings before a notary public only by means of a final judgment adopted in a civil procedure, by virtue of which a court finds that the non-marital union had existed at the time of death of the deceased person. ${ }^{37}$ According to a contrary view, the notary public should resort to litigation only in case of opposition by one of the heirs, i.e., when a dispute on the existence of a non-marital spouse arises. ${ }^{38}$

Although the provision on non-marital spouses being statutory heirs seems like a good solution for the protection of non-marital spouses, it has the potential of having the non-marital spouse imposed as the heir despite the will of the deceased person, since

34 | Zakon o socijalnoj skrbi (The Social Welfare Act), Official Gazette Nos.157/13, 152/14, 99/15, 52/1 6, 16/17, 130/17, 98/19, 64/20 and 138/20.

35 | Zakon o nasljeđivanju (The Inheritance Act), Official Gazette Nos. 48/03, 163/03, 35/05, 127/13, $33 / 15$ and $14 / 19$.

36| The situation is further complicated by the vague provision of Art. 258, Par. 5 of the Family Act according to which only a person placed under guardianship may give consent to enter into life union with persons of different sex. On the other hand, insofar as it concerns personal declaration of will, the consent of a guardian is required for a person deprived of legal capacity to enter into marriage, failing which a court may grant permission (Art. 26 para [2] and Art. 26 para [3] of the Family Act).

$37 \mid C f v$. Josipović, 2003, p. 46

38 | Cfv. Korać, 2003, p. 130 and Crnić, 2003, p. 249. 
he or she was ranked a first-degree heir and accorded the status of a forced heir by the legislature (Art. 69, para. [1] in connection with Art. 8, para [2] of the Inheritance Act). This may particularly be an impediment for elderly persons who are against the new marital or non-marital spouse competing with children from the previous marriage.

The Act on Medically Assisted Procreation ${ }^{39}$ provides that non-marital union refers to the union between a woman and man who do not live in a marriage or same-sex union and meet the conditions to enter into a valid marriage (Art. 11, para. [5]). It is not necessary to ascertain whether non-marital spouses are aware of the conditions for marriage validity under family regulation, which is why general rules dealing with false declarations remain applicable.

Non-marital spouses declare the existence of a non-marital union before the notary public, whose duty is only to certify their signature (Art. 11, para. [3]); prior to any procedure for medically assisted procreation, each beneficiary, even a non-marital spouse, is obliged to give written consent (Art. 14). In a non-marital union, prior to a procedure for medically assisted procreation, the man is obliged to give a certified declaration on being recognised as the father of the child that will be conceived in the procedure, whereas the woman is obliged to give a certified declaration of consent for the recognition of fatherhood of that child (Art.16, para. [2]).

The Act on Rights of Croatian Veterans from the Homeland War and of Members of Their Families ${ }^{40}$ provides that if non-marital spouses had lived with a Croatian veteran from the Homeland War in a common household until his or her death, detention, or disappearance, or had a child out of the non-marital union even if the cohabitation was for a short duration (members of the nuclear family), they can be regarded as a family member. The existence of non-marital unions is to be established in non-contentious court proceedings (Art. 17, para. [1], and Art. 17, para. [2]). By virtue of this regulation, non-marital spouses exercise a series of rights, such as health protection, housing, and rights from pension insurance (Art.18).

The Pension Insurance Act ${ }^{41}$ entitles non-marital spouses to family pensions if they had lived for at least three years in the same household prior to the death of the insured person or pension beneficiary; this regulation also requires that the status of non-marital unions be established in non-contentious court proceedings. It may be noted that this regulation does not encompass a person who has not lived with the insured for three years, even if they have a common child. ${ }^{42}$ When applying this regulation, the case law extended the status of non-marital spouses to persons who had lived less than three years in a non-marital union prior to their partner's death, but there was continuity in the nonmarital union in relation to divorced marriage due to debt evasion. ${ }^{43}$

39 | Zakon o medicinski pomognutoj oplodnji (The Act on Medically Assisted Procreation), Official Gazette No. 86/12.

40 | Zakon o pravima branitelja Domovinskog rata i njihovih članova obitelji (The Act on Rights of Croatian Veterans from Homeland War and of Members of Their Families), Official Gazette Nos. $121 / 17,98 / 19$ and $84 / 21$.

41 | Zakon o mirovinskom osiguranju (The Pension Insurance Act), Official Gazette Nos. 157/13, $151 / 14,33 / 15,93 / 15,120 / 16,18 / 18,62 / 18,115 / 18,102 / 19$ and $84 / 21$.

42 | Cfv. Lucić, 2020, p. 198.

43 | Decision of Zagreb District Court, No. Gž Ob1323/2019-1 of 17 December 2019, according to Lučić, ibid., p. 199. 
The tax regulation ${ }^{44}$ had long opposed the exemption of non-marital spouses from real estate transfer tax, and there is no mention of it in the wording of the act. In that field, the state had been persistently vigilant over its financial interests, and administrative courts had refused to exempt non-marital spouses from real estate taxes, since they relied on the argumentation that tax regulations that represent ius cogens are applicable to rights to exemption from taxation. ${ }^{45}$ Only the Constitutional Court, in 2017, equated the effects of non-marital unions in tax regulations as well. The argumentation it relied on read as follows:

18. Within that framework, the Constitutional Court observes that in the case at hand there was not a semblance of attempt on the part of either the competent administrative authorities or the High Administrative Court to consider the effects of their interpretation, that is, application of law to the applicant's case, in light of the constitutional and conventional prohibition of discrimination, that is, in light of the then development of legislative order in the Republic of Croatia aimed at eliminating the differences between marital and non-marital spouses in case of property relations and inheritance.

During the proceedings before the Constitutional Court, the General Tax Code ${ }^{46}$ provided in 2016 that provisions of tax regulations applicable to marital spouses also apply to non-marital spouses (Art.15, para. 1). This change marked the end of the developments concerning the congruity of effects of marital and non-marital union.

\section{Concluding remarks}

Non-marital union is a sociological phenomenon that is growing in popularity as a lifestyle. Some non-marital unions serve as probationary marriage, and if they witness temporary success, they usually lead up to marriage, especially when the woman becomes pregnant. Recent research shows that young people principally support non-marital union, which, in their opinion, is desirable for the purpose of testing the compatibility of partners and improving the prospect of a happier marriage in the future ${ }^{47}$ The other type of non-marital union is one that reflects a more liberal approach towards living together (especially by making it economically more viable), but it is not inclusive of plans for marriage and is often chosen as an easier way out of life union..$^{48}$

Even the Family Act, which should be sedes materiae for the legal regime of non-marital union, is burdened by deficiencies. The foundation underlying non-marital union is animus and corpus. For animus, a person needs legal capacity or the possibility of making decisions on their personal status. There is no answer in family legislation regarding whether a person lacks the legal capacity to express their will; it is unclear as to how a person deprived of legal capacity insofar as it concerns the status may form a non-marital

44 | Zakon o porezu na promet nekretnina (Act on Real Estate Transfer Tax), Official Gazette, Nos. $115 / 16$ and $106 / 18$.

45 | Amplius Lucić, 2020, pp. 191-193.

$46 \mid$ Opći porezni zakon (General Tax Code), Official Gazette Nos.115/16,106/18,121/19, 32/20 and 42/20.

47 | Research has been conducted among young people in Rijeka. Bandalović, 2017, p. 67.

48 | Ibid., p. 47. 
union and what happens in case they have started to live in a non-marital union that is detrimental to them.

Corpus exists when a woman and man live as co-tenants in some kind of emotional relationship, but if there are no other characteristics of marriage (for example, economic ones), their union does not have to be classified as a non-marital union. ${ }^{49}$ In practice, a problem arose for persons placed in homes for the elderly, who did not want marital effects, but could not be excluded from the purview of non-marital union.

All these complex issues could be subject to subsequent judgements in court proceedings, as the ease of spontaneity coupled with the informal nature of non-marital unions may backfire in the form of long-lasting and complex court proceedings affecting the party wishing to exercise certain rights.

In addition, the family-law solution should have explicitly provided solutions in cases where the formation of a non-marital union has led to the criminal offence of living with a minor or the criminal offence of incest. In the latter case, non-marital union should not produce legal effects, but in the former, the legal order may be opposed by the principle of the best interests of the child (should the child benefit from a non-marital union that constitutes a criminal offence).

The necessity of establishing the existence of non-marital unions is particularly complex because different legal fields envisage different grounds of its existence, with the means of proof ranging from certified declaration before a notary public to non-contentious or contentious court proceedings. ${ }^{50}$ In practice happened that a person who had presented himself as a non-marital spouse of deceived one, had gained family pension after the death of a non-marital spouse and the other person, who represented himself as non-marital spouse of same deceived person, gained the property rights.. Different case law concerning the interpretation of non-marital union increases legal insecurity.

The bona fide path paved by the Croatian legal system on the back of the idea of protecting women as the weaker party in a family union ${ }^{51}$ has led to legal regulation that does not correspond to the fact that there are many similar, yet different non-marital unions based on the wishes and expectations of different individuals. The legislature has misled non-marital spouses based on the idea of protection of women in case of termination of a non-marital union given its informal nature and protection of the principle of autonomy in the free choice of lifestyle, which has been a key argument in the defence of non-marital unions. Many are aware of their rights, but those rights depend heavily on various conditions, so they cannot be aware of all legal obstacles. On the other hand, disarray has been brought about in the legal system, which requires prudent reform capable of improving legal certainty so as to encompass all legal fields regulating the effects of non-marital union.

De lege ferenda, it would be more convenient if non-marital spouses were allowed to make a certified declaration in front of a notary public, with adequate registry of nonmarital declarations capable of being withdrawn by a simple act. This declaration might

49 | Lucić, 2020, p. 136 and Hrabar, 2010, p. 42: 'neither living at the same address nor even sharing of the same bed as a necessity doesn't have to imply ... that they do live in a non-marital union'.

50 | Cfv. Lucić, 2015, pp. 101-131.

51 | The principal advocates of equating marriage and non-marital union are so called women NGOs, motivated by the noble idea of protecting the weaker side, i.e., women.

Available: https://dnevnik.hr/vijesti/hrvatska/udruge-obiteljski-zakon-treba-potpunoizjednaciti-bracnu-i-izvanbracnu-zajednicu---321972.html. (Accessed on 7 September 2021) 
be the proof that a non-marital union exists and has legal effects, provided that onus probandi in on the one claiming to the contrary. 'It is advisable [for non-marital spouses] to...establish their status by a declaration certified before a notary public'. ${ }^{52}$ Furthermore, it is possible that such a declaration of non-marital spouses has to be a requirement for gaining rights towards others. For rights and duties between non-marital spouses, such a declaration might not be necessary.

Yet, attention should be paid to avoid the risk of creating a so-called small marriage, which would have the effects identical to marriage; there exist concerns that parallelism of institutions would undermine the institution of marriage as such.

In the last two decades, we have witnessed a sudden change in the legal approach to non-marital unions and traditional marriages. Non-marital unions have become completely informal marriages. Legal regulations anticipated prevailing social needs. How social changes follow the footsteps of legal changes is to be seen in the population census of this year. It will be interesting to find out what will prevail: tradition and legal certainty or the need not to be bound by matrimonial chains. The good aspect is that the quality of the relationship between spouses in family matters is more important than the form. 


\section{Bibliography}

| Alinčić et al. (2007) Obiteljsko pravo. Zagreb: Narodne novine.

Bandalović, G. (2017) 'Stavovi mladih o kohabitaciji', Revija za socijalnu politiku, 24(1), pp. 45-70.

Crnić, J. (2003) ‘Što je donio novi Zakon o nasljeđivanju', Pravo u gospodarstvu, 42(6), pp. 239-280.

Draškić, M. (1988) Vanbračna zajednica: Građanskopravna dejstva zajedničkog života izvan braka. Beograd: Naučna knjiga.

Draškić, M. (2015) Porodično pravo i prava deteta. Beograd: Pravni fakultet Univerziteta u Beogradu.

Hrabar, D. (2003) 'Obiteljskopravni osvrt na Zakon o nasljeđivanju', Hrvatska pravna revija, 2003/6, pp. 74-84.

Hrabar, D. (2010) 'Neka otvorena pitanja izvanbračne zajednice', Hrvatska pravna revija, 2010/2, pp. 41-48.

Josipović, T. (2003) 'Nasljeđivanje na temelju zakona' in Dika, M. (ed.) Novo nasljednopravno uređenje. Zagreb: Narodne novine.

Korać, A. (2003) ‘Uzdržavanje i imovinski odnosi - promjene i tumačenja’ in Hrabar, D. (ed.) Obiteljski zakon - novine, dvojbe i perspektive. Zagreb: Narodne novine.

Kovaček-Stanić, G. (2007) Porodično pravo. Novi Sad: Pravni fakultet Univerzitet u Novom sadu.

Lucić, N. (2015) ,Dokazivanje izvanbračne zajednice - odgovori na neujednačeno zakonodavstvo i sudsku praksu', Pravni vjesnik, 31(3-4), pp. 101-131.

| Lucić, N. (2020) Izvanbračna zajednica i pravna sigurnost. Zagreb: Narodne novine. 